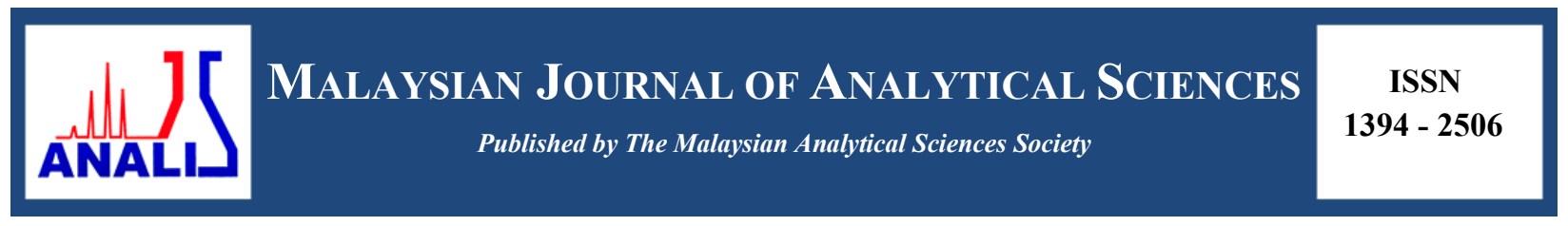

\title{
CO-SENSITIZATION OF NATURAL SENSITIZERS EXTRACTED FROM RENGAS (Gluta spp.) AND MENGKULANG (Heritiera elata) WOOD WITH RUTHENIUM DYE (N719) TO ENHANCE THE PERFORMANCE OF DYE-SENSITIZED SOLAR CELLS
}

\author{
(Ko-Pemekaan Pemeka Semulajadi Disari daripada Kayu Rengas (Gluta Spp.) dan Mengkulang \\ (Heritiera Elata) dengan Pewarna Rutenium (N719) untuk Meningkatkan Prestasi Sel Solar \\ Terpeka Pewarna)
}

Nur Ezyanie Safie ${ }^{1}$, Norasikin Ahmad Ludin ${ }^{1}$, Norul Hisham Hamid ${ }^{2}$, Mohd Sukor Suait ${ }^{1}$, Mohd Asri Mat-Teridi ${ }^{1}$, Suhaila Sepeai ${ }^{1}$, Mohd Adib Ibrahim ${ }^{1}$, Kamaruzzaman Sopian ${ }^{1}$, Hironori Arakawa ${ }^{3}$

\author{
${ }^{1}$ Solar Energy Research Institute (SERI), \\ Universiti Kebangsaan Malaysia, 43600 UKM Bangi, Selangor, Malaysia \\ ${ }^{2}$ Faculty of Forestry, \\ Universiti Putra Malaysia, 43400 Serdang, Selangor, Malaysia \\ ${ }^{3}$ Department of Industrial Chemistry, Faculty of Engineering, \\ Tokyo University of Science, 162-0826, Japan \\ *Corresponding author: sheekeen@ukm.edu.my
}

Received: 12 April 2017; Accepted: 1 September 2017

\begin{abstract}
In this study, photovoltaic performance was improved when two natural sensitizers, namely, rengas (Gluta spp.) and mengkulang (Heritiera elata), were mixed with ruthenium (N719) sensitizer. Five different ratios were prepared and their performances were compared with individual sensitizers. The components of the sensitizers were analyzed via ultraviolet-visible spectrophotometry and Fourier transform infrared spectroscopy. The band gap values and the highest occupied molecular orbital-lowest unoccupied molecular orbital (HOMO-LUMO) levels were calculated using data obtained from photoluminescence analysis and cyclic voltammetry. The mengkulang: N719 (80\%:20\%) sensitizer exhibits the highest conversion efficiency $(\eta)$, which is $0.58 \%$ with an open circuit voltage $\left(V_{\mathrm{oc}}\right)$ of $0.63 \mathrm{~V}$, a short circuit photocurrent density $\left(J_{\mathrm{sc}}\right)$ of $2.1 \mathrm{~mA} / \mathrm{cm}^{2}$, and a fill factor $(f f)$ of 0.44 . By contrast, the individual mengkulang sensitizer presents a poor conversion efficiency $(\eta)$ of $0.16 \%$.
\end{abstract}

Keywords: natural sensitizer, mixed sensitizer, band gap, HOMO-LUMO level

\begin{abstract}
Abstrak
Dalam kajian ini, prestasi fotovoltik telah bertambah baik apabila dua pemeka yang semula jadi, iaitu, rengas (Gluta spp.) dan mengkulang (Heritiera elata), telah di campur dengan pemeka rutenium (N719). Lima nisbah yang berbeza telah disediakan dan prestasi mereka dibandingkan dengan pemeka individu. Komponen pemeka dianalisis melalui spektrofotometri ultralembayung cahaya nampak dan spektroskopi inframerah transformasi Fourier. Nilai jurang jalur dan aras orbit molekul tertinggi yang diduduki - orbit molekul terendah yang diduduki (HOMO-LUMO) dikira menggunakan data yang diperolehi daripada analisis kefotopendarcahayaan dan voltammetri berkitar. Pemeka mengkulang:N719 (80\%: 20\%) mempamerkan kecekapan penukaran tertinggi $(\eta)$, iaitu $0.58 \%$ dengan voltan litar terbuka $\left(V_{\text {oc }}\right) 0.63 \mathrm{~V}$, kepadatan fotoarus litar pintas $\left(J_{\text {sc }}\right) \mathrm{sebanyak} 2.1 \mathrm{~mA} / \mathrm{cm}^{2} \mathrm{dan}$ faktor isi $(f f)$ daripada 0.44 . Sebaliknya, pemeka individu mengkulang memberikan kecekapan penukaran terendah $(\eta) 0.16 \%$.
\end{abstract}

Kata kunci: pemeka semula jadi, pemeka campuran, jurang jalur, aras HOMO-LUMO 


\section{Nur Ezyanie et al: CO-SENSITIZATION OF NATURAL SENSITIZERS EXTRACTED FROM RENGAS (Gluta spp.) AND MENGKULANG (Heritiera elata) WOOD WITH RUTHENIUM DYE (N719) TO ENHANCE THE PERFORMANCE OF DYE-SENSITIZED SOLAR CELLS}

\section{Introduction}

Dye sensitized solar cells (DSSCs) becomes reliable solar cells device as it is reported to promote low cost for material and simple synthesis method in achieving efficient conversion efficiency [1-4]. Basically, DSSCs consists of four components to convert light into electricity which are porous semiconductor, sensitizer, electrolyte and counter electrode. A lot of explorations have been made for each of the components to enhance the effectiveness of DSSCs $[5,6]$. Since sensitizer plays important key roles to absorb light and supply electron for the mechanism in DSSCs, an intense attract to introduce effective sensitizer have led to few types of sensitizer such as metal complexes, metal-free, organic, inorganic, synthetic and natural sensitizers. Each type of sensitizers has their own potential to enhance the conversion efficiency as well as drawbacks that limit their performance [7-10]. A sensitizer that works as a light harvester in dye-sensitized solar cells (DSSCs) is the key to improving the performance of such cells.

Recently, natural dyes have become reliable alternatives for expensive organic, inorganic, or synthetic dyes. Several studies have found that using natural sensitizers have several possible advantages. For example, natural materials can be easily extracted from fruits, flowers, and leaves with minimal procedures; hence, they have attracted considerable interest to produce low-cost and biodegradable sensitizers [11, 12]. Furthermore, such sensitizers are effective because they provide charge carriers and the model cells exhibit similarities to the photosynthetic mechanism [13, 14]. Natural dyes, which are abundant, provide reasonable light harvesting efficiency; they are also sustainable, low cost, and non-toxic $[15,16]$. The most efficient photosensitizer for DSSCs is obtained from ruthenium polypyridyl complexes, such as N719, which exhibits conversion efficiency $(\eta)$ of over 10\% [17]. This characteristic is attributed to metal-to-ligand charge transfer, which produces excited states with long lifetimes, and thus, provides N719 with a broad photon absorption band in the visible spectrum range [18-20]. However, a few drawbacks exhibited by N719 have prompted researchers to seek for another alternative photosensitizer. Although ruthenium exhibits high thermal and chemical stabilities, as well as provides a relatively high efficiency, this trace element is extremely expensive and the demand for it is high; moreover, its sophisticated synthesis and purification processes lead to a high production cost [9]. In addition, ruthenium is a heavy metal, and thus, is a threat to the environment that can pose potential risks even to future generations.

This study aims to investigate experimentally the photovoltaic performance of natural sensitizers extracted from rengas (Gluta spp.) and mengkulang (Heritiera elata) wood. These natural sensitizers are mixed with a low percentage of N719 sensitizer to enhance their cell performances and optical characteristics.

\section{Plants materials and wood extraction}

\section{Materials and Methods}

Rengas and mengkulang wood samples were collected from a local sawmill in Kuala Lumpur, Malaysia. A wood chipper machine and a knife ring chipper were used to obtain fine particles from the wood samples. The particles were then dried in an oven at $60{ }^{\circ} \mathrm{C}$ for 24 hours before they underwent a segregation process according to particle size. The large particles were ground further using a ball mill. The obtained sawdust was then dried in an oven at $130{ }^{\circ} \mathrm{C}$ for 24 hours to decrease its moisture content. To extract dye from the sawdust, methanol was used as the organic solvent in a cold extraction technique. The sawdust was soaked in methanol $(1: 10 \mathrm{w} / \mathrm{v}$ ratio $)$ and left overnight at room temperature. All extraction procedures were performed under dim condition. The glassware that contained the dyes were covered with aluminum foil to minimize photoxidation. Then, the mixture was made to undergo Soxhlet extraction to obtain the extractive compound. The crude extract was stored in a refrigerator $\left(4{ }^{\circ} \mathrm{C}\right.$ ) until further used.

Subsequently, $0.3 \mathrm{mM}$ N719 sensitizer was prepared by mixing $50 \mathrm{~mL}$ acetonitrile (J.T. Baker ${ }^{\circledR}$ Chemicals, PA, USA) and $50 \mathrm{~mL} 4$ tert-butyl alcohol (99.7\%, Sigma-Aldrich Corporation, MO, USA) with $0.036 \mathrm{~g}$ B2 (N719) dye (Dyesol, NSW, Australia). The mixture was left overnight at room temperature before it was ready for use. Apart from the individual sensitizers, we also prepared mixtures of both natural sensitizers with N719 for further analysis. Five different $\mathrm{v} / \mathrm{v}$ ratios were prepared and denoted as mengkulang: N719 (80\%:20\%), mengkulang: N719 (90\%:10\%), mengkulang: rengas: N719 (40\%:40\%:20\%), rengas: N719 (80\%:20\%), and rengas: N719 (90\%:10\%). 


\section{Fabricating DSSCs}

Photoelectrodes were prepared by depositing titanium dioxide $\left(\mathrm{TiO}_{2}\right)$ paste (WER 2-0, Dyesol, NSW, Australia) onto fluorine-doped conducting tin oxide (FTO) glasses $\left(\sim 15 \Omega \mathrm{sq}^{-1}\right.$, Solaronix SA, Aubonne, Switzerland) as conductive glass plates via the doctor-blading technique. The electrodes were then sintered at $450{ }^{\circ} \mathrm{C}$ for 30 minutes. The photoelectrodes were subsequently dipped into their respective sensitizers, namely, mengkulang, rengas, and their mixtures [mengkulang: N719 (80\%:20\%), mengkulang: N719 (90\%:10\%), mengkulang: rengas: N719 (40\%:40\%:20\%), rengas: N719 (80\%:20\%), and rengas: N719 (90\%:10\%)], for 24 hours at room temperature to allow sufficient time for the dye molecules to be absorbed onto $\mathrm{TiO}_{2}$ surface. Then, the $\mathrm{TiO}_{2}$ electrodes were removed and rinsed with methanol before being dried with nitrogen gas. The DSSCs were assembled by introducing the redox electrolyte (iodolyte AN-50, Solaronix SA, Aubonne, Switzerland) between the dyed $\mathrm{TiO}_{2}$ electrode and the platinum counter electrode. The platinum paste purchased from Solaronix was deposited onto FTO glasses $(\sim 8$ $\Omega \mathrm{sq}^{-1}$, Solaronix SA, Aubonne, Switzerland) and heated at $450{ }^{\circ} \mathrm{C}$ for 30 minutes. Surlyn ${ }^{\circledR}(60 \mu \mathrm{m}$, Meltonix 1170-60, Solaronix SA, Aubonne, Switzerland) was used to assemble the photo electrode and the counter electrode of the cell.

\section{Characterization and device performance}

The absorption spectra were obtained using an ultraviolet-visible (UV-Vis) absorption spectrophotometer (UV1800, Shimadzu Corporation, Kyoto, Japan). The functional groups of the sensitizers were determined via Fourier transformed infrared spectroscopy (FTIR) using the Spectrum 400 FTIR Imaging System (PerkinElmer, Inc., MA, USA). The highest occupied molecular orbital (HOMO) and the lowest unoccupied molecular orbital (LUMO) were determined by photoluminescence (PL) analysis using FLSP920 fluorescence spectrometer (Edinburgh Instruments, Ltd., Livingston, UK) and cyclic voltammetry (CV) using the ModuLab system (Solartron Analytical, PA, USA). The CV measurements consist of three electrodes, namely, glassy carbon working electrode, platinum counter electrode, and silver/silver chloride $(\mathrm{Ag} / \mathrm{AgCl})$ reference electrode, at a scan rate of $100 \mathrm{mV} / \mathrm{s}$. In this study, $0.1 \mathrm{M}$ lithium perchlorate $\left(\mathrm{LiClO}_{4}\right)$ is used as the supporting electrolyte. Current-voltage $(I-V)$ measurement was conducted using a class AAA solar simulator (XES-40S1, San-Ei Electric Co., Ltd., Osaka, Japan) under an irradiation of $1000 \mathrm{~W} / \mathrm{m}^{2}$. The maximum power conversion efficiency $(\eta)$ was calculated using the following formula in equation 1 :

$$
\mathrm{\eta}=f f \times I_{\mathrm{sc}} \times V_{\mathrm{oc}} / P
$$

where $f f$ is the fill factor, $I_{\mathrm{sc}}$ is the short circuit photo current density $\left(\mathrm{A} / \mathrm{cm}^{2}\right), V_{\mathrm{oc}}$ is the open circuit voltage $(\mathrm{V})$, and $P$ is the intensity of the incident light $\left(\mathrm{W} / \mathrm{cm}^{2}\right)$ of the DSSC. The fill factor $(f f)$ was defined using the following equation 2:

$$
F F=\left(I_{\max } \times V_{\max }\right) /\left(I_{\mathrm{sc}} \times V_{\mathrm{oc}}\right)
$$

where $I_{\max }$ and $V_{\max }$ represent the maximum output value of the current and voltage, respectively; while $I_{\mathrm{sc}}$ and $V_{\mathrm{oc}}$ represent the short-circuit current and open-circuit voltage, respectively. Incident photon-to-current efficiency (IPCE) was also measured using a spectral response measurement system (IVT Solar PVE-300, Bentham Instruments, Ltd., Berkshire, UK).

\section{UV-Vis analysis}

\section{Results and Discussion}

The extracted crude sensitizers from rengas and mengkulang wood were examined under a UV-Vis spectrophotometer with methanol as the solvent reference. The absorption spectra of the crude sensitizers are shown in Figure 1. The intense peaks were found at $400 \mathrm{~nm}$ and $512 \mathrm{~nm}$, which were observed in the rengas sensitizer. However, a broad shoulder appeared between $420 \mathrm{~nm}$ to $550 \mathrm{~nm}$, which represented the mengkulang sensitizer. Based on these data, the rengas sensitizer can exhibit strong absorption at low wavelengths. Moreover, Figure 2 illustrates the absorption spectra of the mengkulang and rengas mixtures with the N719 sensitizer at five different percentage ratios. As shown in the figure, the absorption spectra of mengkulang: rengas: N719 (40\%:40\%:20\%), rengas: N719 (80\%:20\%), and rengas: N719 (90\%:10\%) exhibit similarity to that of the individual rengas sensitizer. This finding may be attributed to the chemical characteristic of the rengas sensitizer, which is more dominantly 
Nur Ezyanie et al: CO-SENSITIZATION OF NATURAL SENSITIZERS EXTRACTED FROM RENGAS (Gluta spp.) AND MENGKULANG (Heritiera elata) WOOD WITH RUTHENIUM DYE (N719) TO ENHANCE THE PERFORMANCE OF DYE-SENSITIZED SOLAR CELLS

absorbed onto $\mathrm{TiO}_{2}$ surface compared with the other sensitizers. Moreover, the absorption spectra of mengkulang: N719 (80\%:20\%) and mengkulang: N719 (90\%:10\%) also exhibit similarity to that of the individual mengkulang sensitizer because of the dominant effect of this sensitizer over the N719 sensitizer.

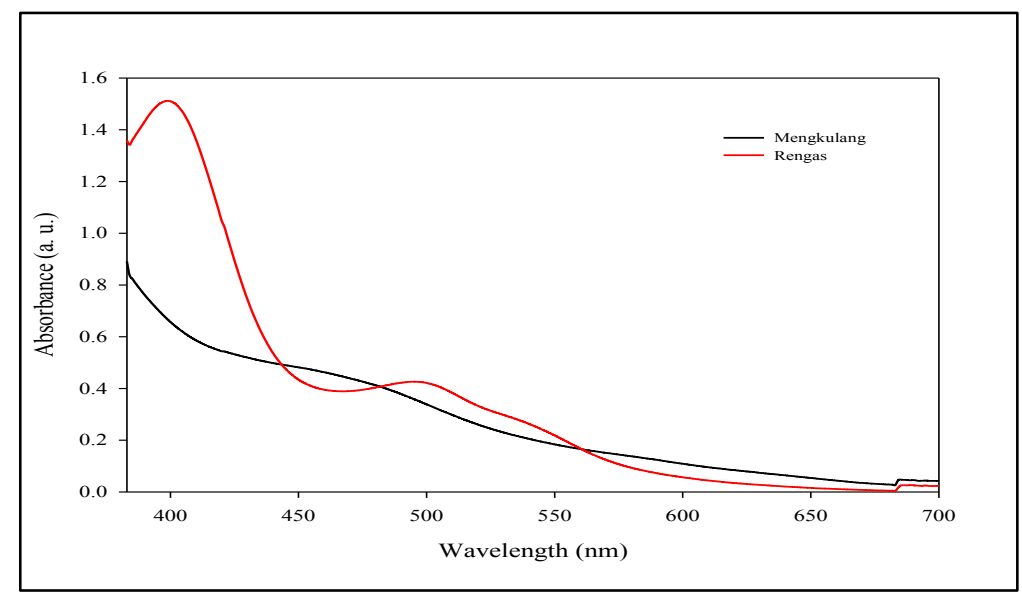

Figure 1: UV-Vis absorption spectra of the mengkulang and rengas sensitizers

In addition, the absorption spectra of the mixed sensitizers absorbed onto $\mathrm{TiO}_{2}$ are also shown in Figure 2. Upon absorbed onto $\mathrm{TiO}_{2}$, the spectra did not present an obvious peak although wide shoulders were observed between $400 \mathrm{~nm}$ and $450 \mathrm{~nm}$ and between $500 \mathrm{~nm}$ and $550 \mathrm{~nm}$ for mengkulang: rengas: N719 (40\%:40\%:20\%), rengas: N719 (80\%:20\%), and rengas: N719 (90\%:10\%), as well as between $500 \mathrm{~nm}$ and $550 \mathrm{~nm}$ for mengkulang: N719 (80\%:20\%) and mengkulang: $\mathrm{N} 719$ (90\%:10\%). The UV-Vis absorption of $\mathrm{TiO}_{2}$ without a sensitizer is also shown to compare it with those with absorbed sensitizers. Based on the comparison results, the absorption spectra of the sensitizers absorbed onto $\mathrm{TiO}_{2}$ exhibit a more stable and broader shoulder than that of $\mathrm{TiO}_{2}$ without a sensitizer; this characteristic enables the photoelectrode to harvest light from a broad spectrum of solar energy, which causes a device to generate high photocurrent [21]. Another important finding is that dye concentration also affects absorption value.

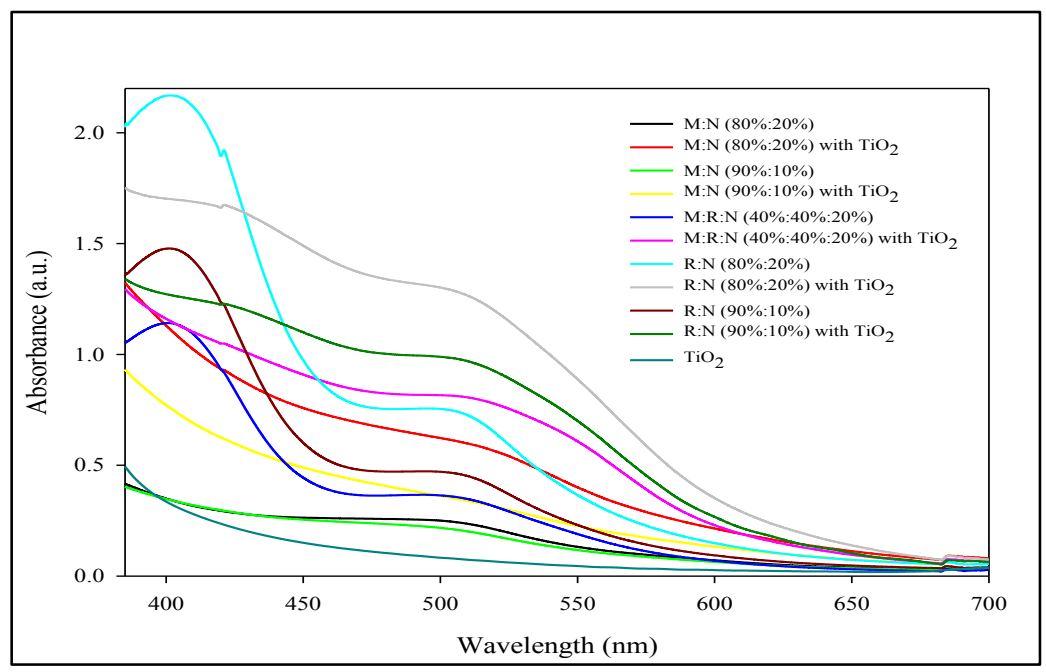

Figure 2. UV-Vis absorption of the mixed sensitizers, the $\mathrm{TiO}_{2}$ electrode, and the sensitizers absorbed onto $\mathrm{TiO}_{2}$ ( $\mathrm{M}$ stands for mengkulang; $\mathrm{N}$ denotes N719; and R indicates rengas). 


\section{FTIR analysis}

The functional groups of the sensitizers were analyzed via FTIR spectroscopy, with potassium bromide as the background reference. Figure 3 shows that the patterns of the infrared spectra are similar for all samples probably because the functional groups present in all the investigated sensitizers are the same. The broad bands observed at $3323,3309,3340,3352$, and $3320 \mathrm{~cm}^{-1}$ were attributed to the vibrations of the free hydroxyl group ( $\left.\mathrm{Ar}-\mathrm{O}-\mathrm{H}\right)$ of phenols. The intense peaks observed at $2832 \mathrm{~cm}^{-1}$ and $2944 \mathrm{~cm}^{-1}$ were attributed to the stretching of the $s p^{3} \mathrm{C}-\mathrm{H}$ bond. Moreover, the small shoulder that appeared at $1449 \mathrm{~cm}^{-1}$ was ascribed to the presence of aromatic $\mathrm{C}=\mathrm{C}$ stretching, whereas the one observed at $1650 \mathrm{~cm}^{-1}$ was attributed to the presence of a $\mathrm{C}=\mathrm{N}$ bond. The intense and long peak at $1023 \mathrm{~cm}^{-1}$ was ascribed to the presence of a $\mathrm{C}-\mathrm{O}$ bond. Based on the collected information, the carboxyl and carbonyl functional groups do not exist in the studied natural sensitizers. Previous literature has reported that the functional group that is required to interact with $\mathrm{TiO}_{2}$ surface is either a carboxylic group or other peripheral acidic anchoring groups [22].

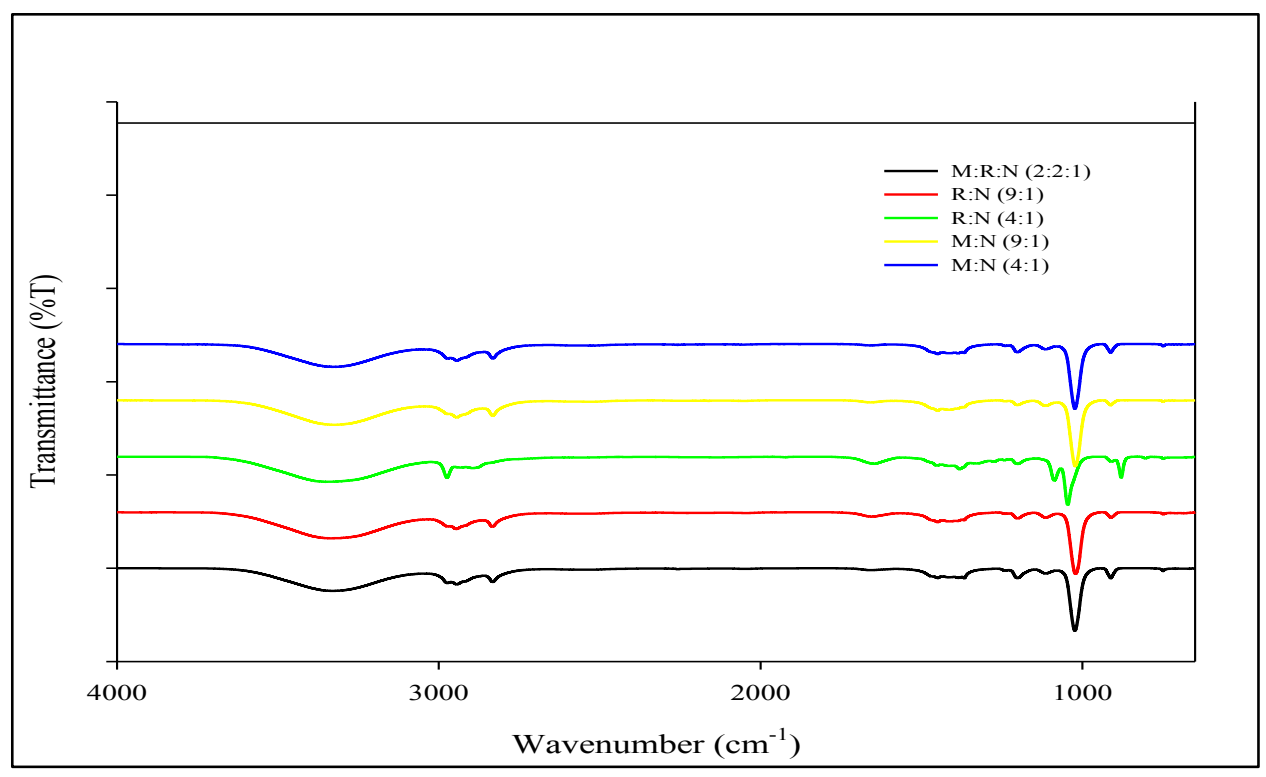

Figure 3. FTIR analyses of the individual and mixed sensitizers ( $M$ stands for mengkulang; $N$ denotes N719; and R indicates rengas)

\section{PL Analysis}

Band gap measurement was performed via PL analysis. The optical band gaps of the sensitizers were obtained from the relation $E_{\mathrm{g}}=h c \lambda$, where $h$ is Planck's constant, $c$ is the speed of light, and $\lambda$ is the emission peak obtained from the PL emission spectra. Table 1 provides the band gap measurements of all types of samples used in this study. Based on the data, the mengkulang and mengkulang: N719 (80\%:20\%) sensitizers exhibit the highest band gap value, that is, $2.38 \mathrm{eV}$, at the emission peaks of $522 \mathrm{~nm}$ and $520 \mathrm{~nm}$, respectively. Furthermore, the mengkulang: N719 (90\%:10\%) sensitizer presents a slightly lower band gap value, that is, $2.36 \mathrm{eV}$ at the emission peak of 525 $\mathrm{nm}$. The remaining samples exhibit close band gap value of $2.15 \mathrm{eV}$ for both the rengas sensitizer at the emission peak of $576 \mathrm{~nm}$ and the rengas: N719 (80\%:20\%) sensitizer at the emission peak of $578 \mathrm{~nm}$. The band gap value of $2.16 \mathrm{eV}$ was obtained for both the mengkulang: N719 (80\%:20\%) and mengkulang: rengas: N719 (40\%:40\%:20\%) sensitizers at the same emission peak of $575 \mathrm{~nm}$. As shown in Figure 4, the mengkulang, mengkulang: N719 (80\%:20\%), and mengkulang: N719 (90\%:10\%) sensitizers have broad emission peaks, whereas the other sensitizers exhibit similar emission peak patterns. In addition, $90 \%$ and $80 \%$ mengkulang present higher intensity than $90 \%$ and $80 \%$ rengas in the mixed sensitizers. Moreover, the mixed sensitizers with $10 \%$ N719 have higher intensities than those with $20 \%$ N719. 
Nur Ezyanie et al: CO-SENSITIZATION OF NATURAL SENSITIZERS EXTRACTED FROM RENGAS (Gluta spp.) AND MENGKULANG (Heritiera elata) WOOD WITH RUTHENIUM DYE (N719) TO ENHANCE THE PERFORMANCE OF DYE-SENSITIZED SOLAR CELLS

Table 1. Summary of optical band gap measurement

\begin{tabular}{lcc}
\hline Sensitizer & $\boldsymbol{\lambda} \boldsymbol{\operatorname { m a x }}(\mathbf{n m})$ & $\boldsymbol{E}_{\mathbf{g}}=\boldsymbol{h} \boldsymbol{c} \boldsymbol{\lambda}(\mathbf{e V})$ \\
\hline Mengkulang (M) & 522 & 2.38 \\
Rengas (R) & 576 & 2.15 \\
M:R:N (40\%:40\%:20\%) & 575 & 2.16 \\
M:N (90\%:10\%) & 525 & 2.36 \\
M:N (80\%:20\%) & 520 & 2.38 \\
R:N (90\%:10\%) & 575 & 2.16 \\
R:N (80\%:20\%) & 578 & 2.15 \\
\hline
\end{tabular}

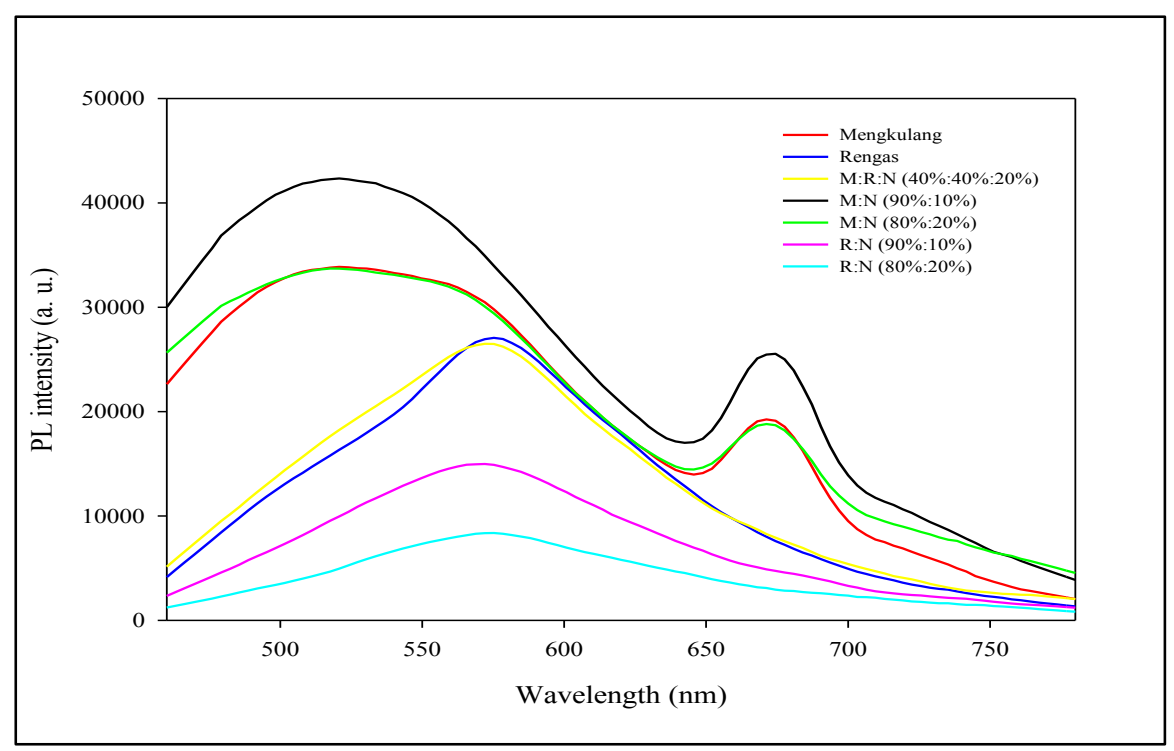

Figure 4. Emission spectra of the individual and mixed sensitizers ( $\mathrm{M}$ stands for mengkulang; $\mathrm{N}$ denotes N719; and $\mathrm{R}$ indicates rengas

\section{Cyclic voltammetry analysis}

The HOMO-LUMO was calculated via CV [23]. The cyclic voltammograms of mengkulang, rengas, mengkulang: N719 (80\%:20\%), mengkulang: N719 (90\%:10\%), mengkulang: rengas: N719 (40\%:40\%:20\%), rengas: N719 (80\%:20\%), and rengas: N719 (90\%:10\%) are presented in Figure 5. The calculated positions of the HOMO and LUMO levels are presented in Table 2 with respect to their individual reduction potential onset extrapolated from the voltammograms of the sensitizers [24]. Based on the HOMO-LUMO levels presented in Table 2, schematics were illustrated in Figures 6 and 7 to compare the energy levels of the investigated sensitizers in terms of vacuum level and normal hydrogen electrode (NHE). 
Table 2. Calculated HOMO-LUMO energy levels and band gap measurements

\begin{tabular}{lcccc}
\hline Sensitizer & $\begin{array}{c}\text { Band Gap, } \\
\boldsymbol{E}_{\mathbf{g}}(\mathbf{e V})\end{array}$ & $\begin{array}{c}\boldsymbol{E}_{\mathbf{o x}}{ }^{\text {onset }} \mathbf{v s} \\
\mathbf{A g} / \mathbf{A g C l}(\mathbf{V})\end{array}$ & $\begin{array}{c}\text { LUMO Level } \\
(\mathbf{e V})\end{array}$ & $\begin{array}{c}\text { HOMO Level } \\
(\mathbf{e V})\end{array}$ \\
\hline Mengkulang (M) & 2.38 & 0.29 & -2.31 & -4.69 \\
Rengas (R) & 2.15 & 0.26 & -2.51 & -4.66 \\
M:N (80\%:20\%) & 2.38 & 0.27 & -2.29 & -4.67 \\
M:N (90\%:10\%) & 2.36 & 0.32 & -2.36 & -4.72 \\
M:R:N (40\%:40\%:20\%) & 2.16 & 0.32 & -2.56 & -4.72 \\
R:N (80\%:20\%) & 2.15 & 0.27 & -2.52 & -4.67 \\
R:N (90\%:10\%) & 2.16 & 0.31 & -2.55 & -4.71 \\
\hline
\end{tabular}

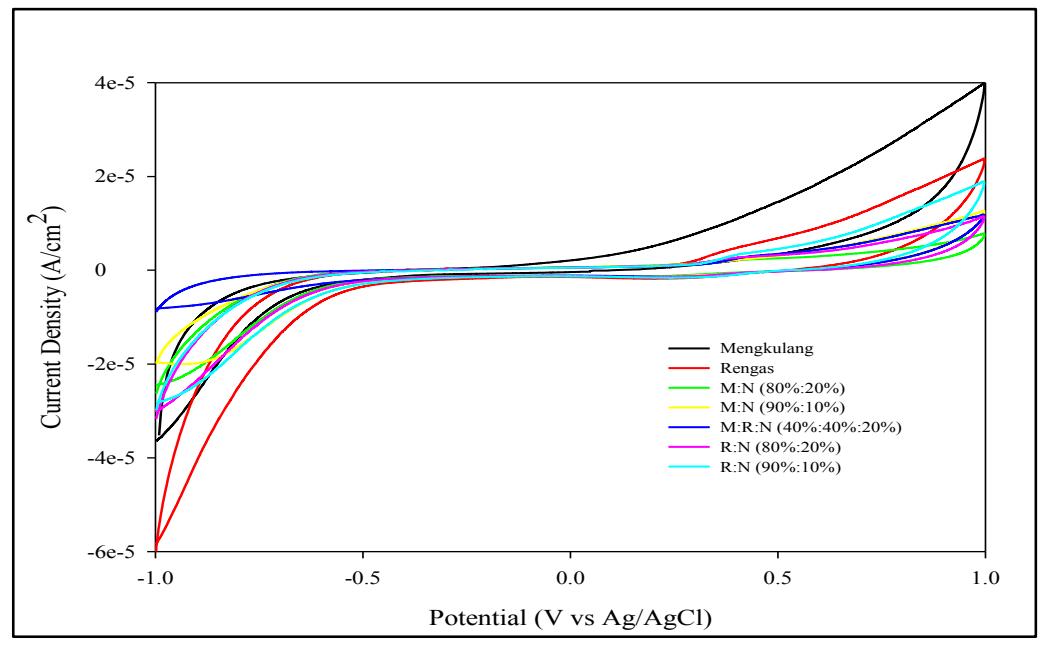

Figure 5. Cyclic voltammograms of the individual and mixed sensitizers ( $\mathrm{M}$ stands for mengkulang; $\mathrm{N}$ denotes $\mathrm{N} 719$; and $\mathrm{R}$ indicates rengas)

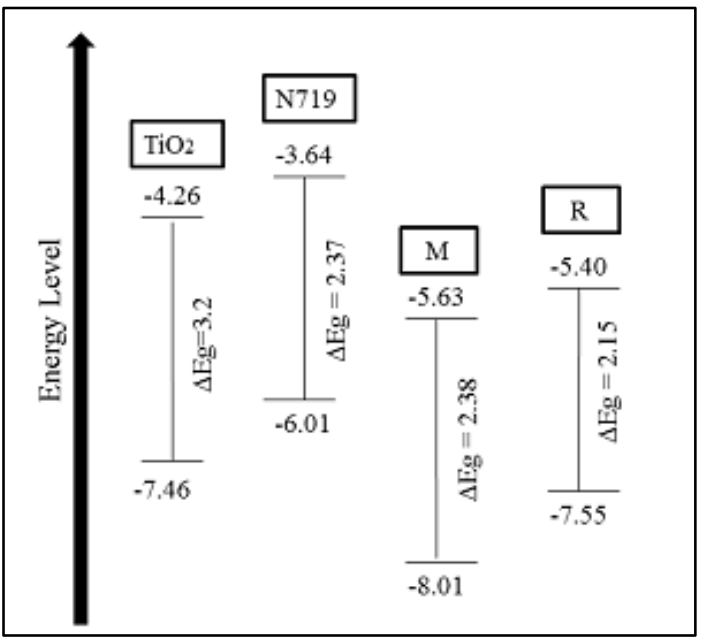

Figure 6. Schematic of the energy levels of $\mathrm{TiO}_{2}$ and the $\mathrm{N} 719$, mengkulang, and rengas sensitizers with respect to vacuum level and NHE (M stands for mengkulang and $\mathrm{R}$ denotes rengas) 


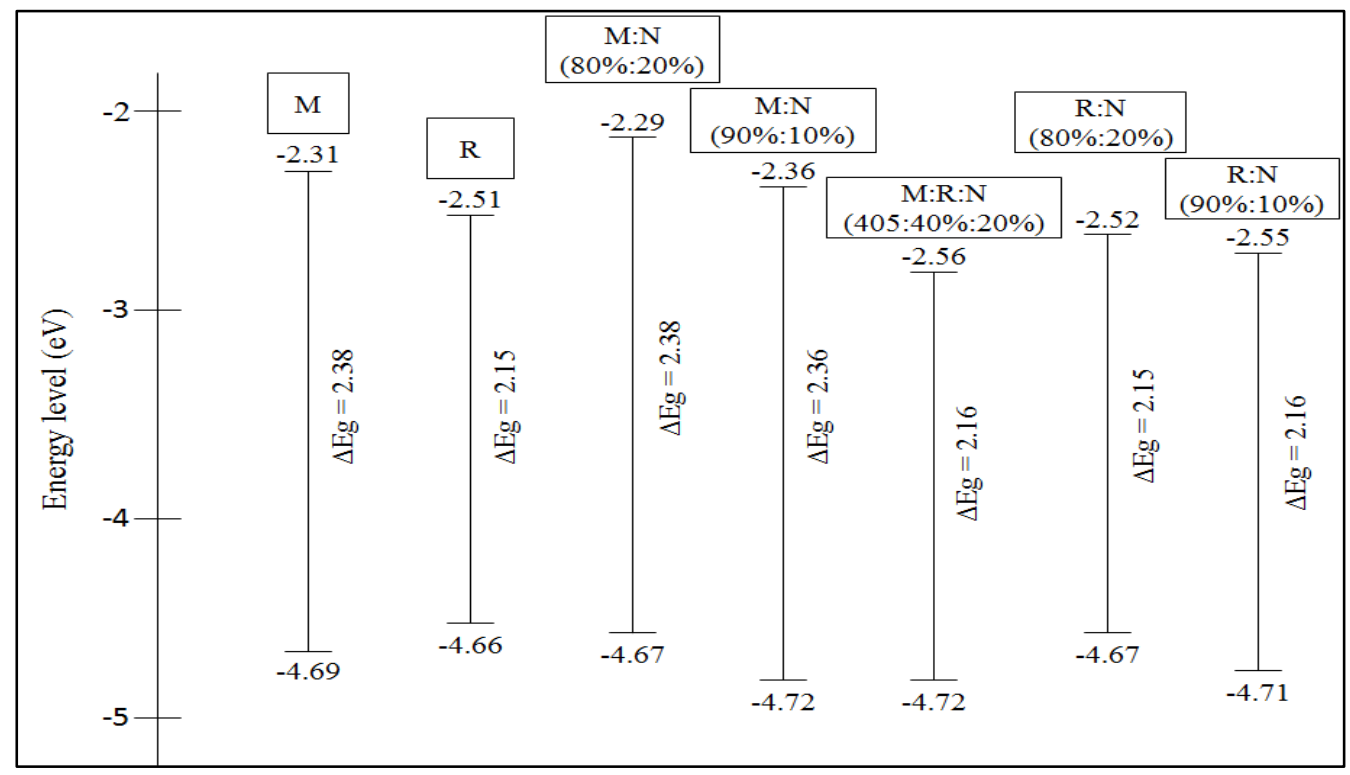

Figure 7. Schematic of the comparison of the energy levels of the investigated sensitizers with respect to vacuum level and NHE (M stands for mengkulang; N denotes N719; and R indicates rengas)

As shown in Figures 6 and 7, the LUMO levels of mengkulang, rengas, mengkulang: N719 (80\%:20\%), mengkulang: N719 (90\%:10\%), mengkulang: rengas: N719 (40\%:40\%:20\%), rengas: N719 (80\%:20\%), and rengas: $\mathrm{N} 719$ (90\%:10\%) were located below the conduction band (CB) of $\mathrm{TiO}_{2}$. By contrast, the LUMO level of a sensitizer must be located slightly above the energy level of a semiconductor to enable the sensitizer to inject electrons into the conduction band of $\mathrm{TiO}_{2}$ with high quantum yields [25]. Given that the LUMO levels of the investigated sensitizers obtained in this study are lower than the $\mathrm{CB}$ level of $\mathrm{TiO}_{2}$, the performance of the cells is predicted to be poor.

\section{I-V characteristics}

Figure 8 shows the $I-V$ curve of the mengkulang, rengas, mengkulang: N719 (80\%:20\%), mengkulang: N719 (90\%:10\%), mengkulang: rengas: N719 (40\%:40\%:20\%), rengas: N719 (80\%:20\%), and rengas: N719 (90\%:10\%) sensitizers evaluated under the illumination of AM 1.5 global simulated solar light. The performances of the DSSCs are calculated and the results are presented in Table 3. The best performance is exhibited by the mengkulang: N719 ( $80 \%: 20 \%)$ sensitizer, which presents a conversion efficiency $(\eta)$ of $0.58 \%$, with an open circuit voltage $\left(V_{\text {oc }}\right)$ of $0.63 \mathrm{~V}$, a short circuit photocurrent density $\left(J_{\mathrm{sc}}\right)$ of $2.1 \mathrm{~mA} / \mathrm{cm}^{2}$, and a fill factor $(f f)$ of 0.44 . The mengkulang: N719 (90\%:10\%) sensitizer follows with a conversion efficiency $(\eta)$ of $0.45 \%, V_{\text {oc }}$ of $0.606 \mathrm{~V}, J_{\text {sc }}$ of $1.7 \mathrm{~mA} / \mathrm{cm}^{2}$, and $f f$ of 0.44 under an irradiance of $1000 \mathrm{~W} / \mathrm{m}^{2}$. Moreover, the other mixed sensitizers exhibit lower conversion efficiencies than the two synthesizers but still higher than those of the individual sensitizers, namely, mengkulang and rengas. Between these two, mengkulang achieves higher conversion efficiency $(\eta)$ of $0.16 \%$, with $V_{\text {oc }}$ of $0.53 \mathrm{~V}$, $J_{\mathrm{sc}}$ of $0.4 \mathrm{~mA} / \mathrm{cm}^{2}$, and $f f$ of 0.76 . Meanwhile, rengas has conversion efficiency $(\eta)$ of $0.11 \%, V_{\mathrm{oc}}$ of $0.5 \mathrm{~V}, J_{\mathrm{sc}}$ of 0.3 $\mathrm{mA} / \mathrm{cm}^{2}$, and $f f$ of 0.73 . Based on the obtained data, the $J_{\mathrm{sc}}$ value is directly proportional to conversion efficiency $(\eta)$. Ooyama et al. [26] reported that the $J_{\text {sc }}$ value is dependent on the interaction between $\mathrm{TiO}_{2}$ and the dye sensitizer. A high $J_{\mathrm{sc}}$ value directly indicates strong light-absorption capability and high electron-injection efficiency for a photoexcited dye. Hence, a high $J_{\mathrm{sc}}$ value will contribute to increasing conversion efficiency $(\eta)$. 


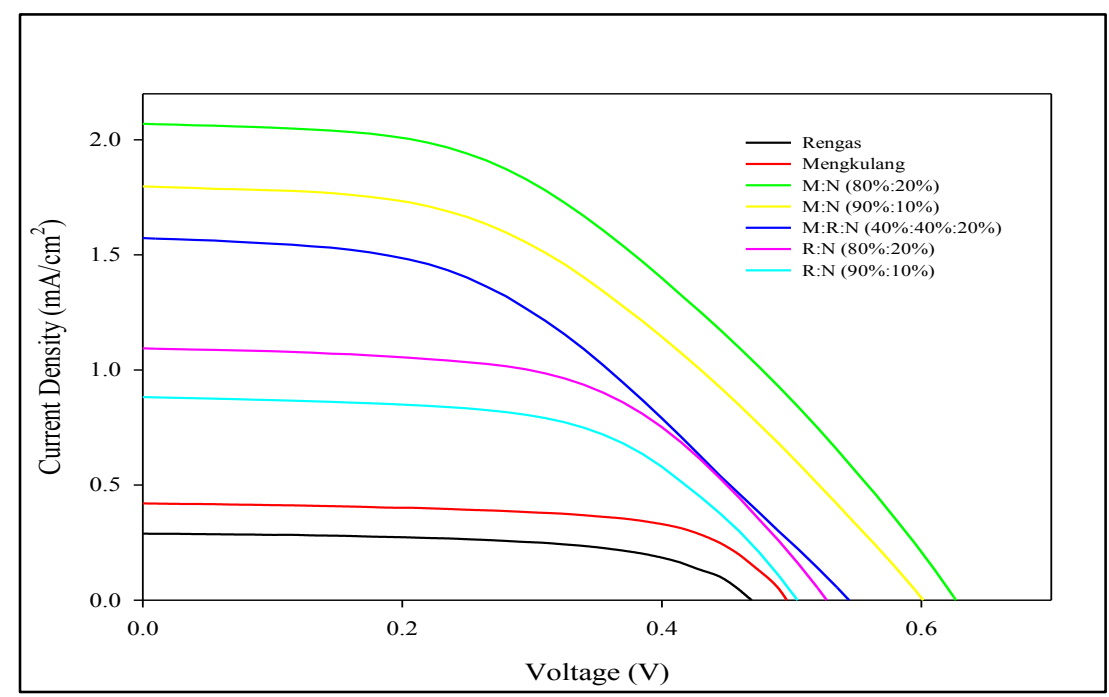

Figure 8. Comparison of the $I-V$ characteristics of the individual and mixed sensitizers (M stands for mengkulang; $\mathrm{N}$ denotes $\mathrm{N} 719$; and $\mathrm{R}$ indicates rengas)

Table 3. $I-V$ characteristics and power conversion efficiencies $(\eta)$ of DSSCs with different type of sensitizers

\begin{tabular}{lcccc}
\hline Sensitizer & $\begin{array}{c}\boldsymbol{V}_{\text {oc }} \\
(\mathbf{V})\end{array}$ & $\begin{array}{c}\boldsymbol{J}_{\mathbf{s c}} \\
\left(\mathbf{m A ~ c m}^{-2}\right)\end{array}$ & $\boldsymbol{f f}$ & $\boldsymbol{\eta} / \%$ \\
\hline Mengkulang (M) & 0.53 & 0.40 & 75.98 & 0.16 \\
Rengas (R) & 0.50 & 0.30 & 72.88 & 0.11 \\
M:N (80\%:20\%) & 0.63 & 2.10 & 44.00 & 0.58 \\
M:N (90\%:10\%) & 0.61 & 1.70 & 44.41 & 0.46 \\
M:R:N (40\%:40\%:20\%) & 0.55 & 1.60 & 45.23 & 0.39 \\
R:N (80\%:20\%) & 0.53 & 1.10 & 57.07 & 0.33 \\
R:N (90\%:10\%) & 0.56 & 0.70 & 65.03 & 0.25 \\
\hline
\end{tabular}

\section{IPCE spectra}

Figure 9 shows the IPCE spectra of all the investigated sensitizers. As shown in the figure, the mengkulang: N719 (80\%:20\%) and mengkulang: N719 (90\%:10\%) sensitizers exhibit the highest efficiency with two similar intense peaks at $354 \mathrm{~nm}$ and $540 \mathrm{~nm}$, respectively. Meanwhile, the mengkulang: rengas: N719 (40\%:40\%:20\%), rengas: N719 (80\%:20\%), and rengas: N719 (90\%:10\%) sensitizers present similar curve patterns, where mengkulang: rengas: N719 (40\%:40\%:20\%) has the highest efficiency, followed by rengas: N719 (80\%:20\%) and rengas: N719 (90\%:10\%). Both the individual sensitizers, namely, mengkulang and rengas, exhibit lower efficiencies compared with the mixed sensitizers, which are parallel to their lower efficiency in $I-V$ characteristics. The results in IPCE percentage agree with the $I-V$ data collected in this study. They are consistent with the findings of Kumara et al. [23], wherein low IPCE contributes to the low energy conversion efficiency $(\eta)$ of a DSSC. 


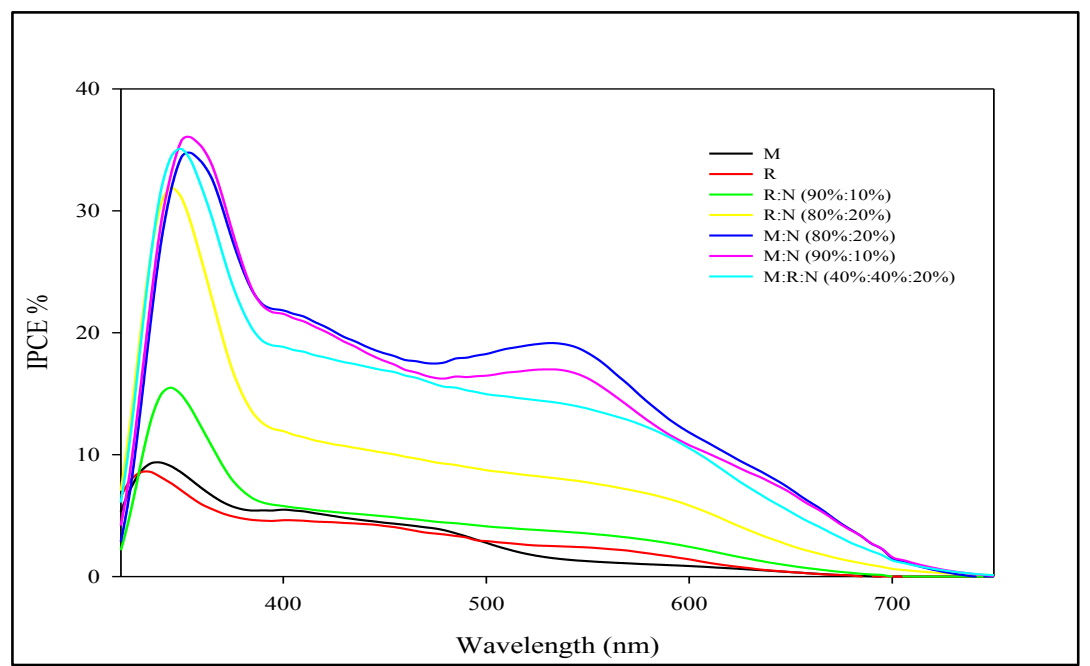

Figure 9. IPCE spectra of the individual and mixed sensitizers (M stands for mengkulang; $N$ denotes N719; and R indicates rengas)

\section{Conclusion}

This study reveals the enhanced performance of DSSCs with natural sensitizers extracted from rengas and mengkulang mixed with N719 sensitizer. The best performance is exhibited by the mengkulang: N719 (80\%:20\%) sensitizer, with a conversion efficiency $(\eta)$ of $0.584 \%$. This conversion efficiency shows an increment compared with the individual mengkulang sensitizer $(0.161 \%)$. The mixed sensitizers present better photovoltaic performance than the individual sensitizers across all analyses. Their IPCE and $I-V$ curves demonstrate parallel results. For example, mengkulang and rengas have low IPCE percentages, which contribute to low conversion efficiency. The HOMO and LUMO levels of all the investigated sensitizers have been calculated to determine their capability to inject electrons into the $\mathrm{CB}$ of $\mathrm{TiO}_{2}$. The LUMO levels of all the investigated sensitizers are located below the Fermi level of $\mathrm{TiO}_{2}$, which results in low conversion efficiency (y). Although the efficiencies obtained using these natural sensitizers remain too low for large-scale practical applications, the obtained results may motivate researchers to conduct studies to explore these natural sensitizers further.

\section{Acknowledgements}

This research was supported by Universiti Kebangsaan Malaysia under Iconic Collaboration Grant (ICONIC-2013006) and presented in UKM-UCA international joint seminar on Science and Technology 2016.

\section{References}

1. Hua, Y., Chang, S., Wang, H., Huang, D., Zhao, J., Chen, T. and Zhu, X. (2013). New phenothiazine-based dyes for efficient dye-sensitized solar cells: Positioning effect of a donor group on the cell performance. Journal of Power Sources, 243: 253-259.

2. Chang, J., Lee, C., Kumar, D., Chen, P., Lin, L., Thomas, K. R. J. and Ho, K. (2013). Co-sensitization promoted light harvesting for organic dye-sensitized solar cells using unsymmetrical squaraine dye and novel. Journal of Power Sources, 240: 779-785.

3. Namuangruk, S., Fukuda, R., Ehara, M., Meeprasert, J., Khanasa, T., Morada, S., Kaewin, T., Jungsuttiwong,

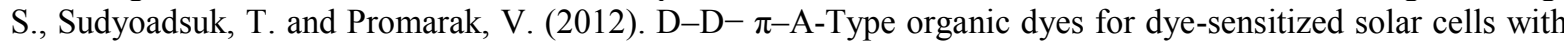
a potential for direct electron injection and a high extinction coefficient: synthesis, characterization, and theoretical investigation. The Journal of Physical Chemistry C, 116(49): 25653-25663.

4. Pei, K., Wu, Y., Islam, A., Zhu, S., Han, L., Geng, Z. and Zhu, W. (2014). Dye-sensitized solar cells based on quinoxaline dyes: effect of $\pi$ - linker on absorption, energy levels, and photovoltaic performances, The Journal of Physical Chemistry C, 118(30): 16552-16561. 
5. Hamadanian, M., Jabbari, V. and Gravand, A. (2012). Materials science in semiconductor processing dependence of energy conversion efficiency of dye-sensitized solar cells on the annealing temperature of $\mathrm{TiO}_{2}$ nanoparticles. Materials Science in Semiconductor Processing, 15(4): 371-379.

6. Lee, J. P., Yoo, B., Suresh, T., Kang, M. S., Vital, R. and Kim, K. J. (2009). Novel silane-substituted benzimidazolium iodide as gel electrolyte for dye-sensitized solar cells. Electrochimica Acta, 54(18): 43654370 .

7. Torchani, A., Saadaoui, S., Gharbi, R. and Fathallah, M. (2015). Sensitized solar cells based on natural dyes. Current Applied Physics, 15(3): 307-312.

8. Ludin, N. A., Al-Alwani Mahmoud, A. M., Bakar Mohamad, A., Kadhum, A. A. H., Sopian, K. and Abdul Karim, N. S. (2014). Review on the development of natural dye photosensitizer for dye-sensitized solar cells. Renewable and Sustainable Energy Reviews, 31: 386-396.

9. Gong, J., Liang, J. and Sumathy, K. (2012). Review on dye-sensitized solar cells (DSSCs): Fundamental concepts and novel materials. Renewable and Sustainable Energy Reviews, 16(8), 5848-5860.

10. Polo, A. S., Itokazu, M. K. and Murakami Iha, N. Y. (2004). Metal complex sensitizers in dye-sensitized solar cells. Coordination Chemistry Reviews, 248(13-14), 1343-1361.

11. Richhariya, G., Kumar, A., Tekasakul, P. and Gupta, B. (2017). Natural dyes for dye-sensitized solar cell: A review. Renewable and Sustainable Energy Reviews, 69: 705-718.

12. Hamadanian, M., Safaei-Ghomi, J., Hosseinpour, M., Masoomi, R. and Jabbari, V. (2014). Uses of new natural dye photosensitizers in fabrication of high potential dye-sensitized solar cells (DSSCs). Materials Science in Semiconductor Processing, 27: 733-739.

13. Koyama, Y., Miki, T., Wang, X. F. and Nagae, H. (2009). Dye-sensitized solar cells based on the principles and materials of photosynthesis: Mechanisms of suppression and enhancement of photocurrent and conversion efficiency. International Journal of Molecular Sciences, 10(11): 4575-4622.

14. Kalyanasundaram, K. and Graetzel, M. (2010). Artificial photosynthesis: Biomimetic approaches to solar energy conversion and storage. Current Opinion in Biotechnology, 21(3): 298-310.

15. Shahid, M., Shahid-Ul-Islam and Mohammad, F. (2013). Recent advancements in natural dye applications: A review. Journal of Cleaner Production, 53: 310-331.

16. Hao, S., Wu, J., Huang, Y. and Lin, J. (2006). Natural dyes as photosensitizers for dye-sensitized solar cell. Solar Energy, 80(2): 209-216.

17. Nazeeruddin, M. K., Péchy, P., Renouard, T., Zakeeruddin, S. M., Humphry-Baker, R., Comte, P., Liska, P., Cevey, L., Costa, E., Shklover, V. and Spiccia, L. (2001). Engineering of efficient panchromatic sensitizers for nanocrystalline $\mathrm{TiO}_{2}$-based solar cells. Journal of the American Chemical Society, 123(8): 1613-1624.

18. Nwanya, A. C., Ezema, F. I. and Ejikeme, P. M. (2011). Dyed sensitized solar cells: A technically and economically alternative concept to p-n junction photovoltaic devices. International Journal of the Physical Sciences, 6(22): 5190-5201.

19. Ahn, J., Lee, K.C., Kim, D., Lee, C., Lee, S., Cho, D.W., Kyung, S. and Im, C. (2013). Synthesis of novel ruthenium dyes with thiophene or thienothiophene substituted terpyridyl ligands and their characterization. Molecular Crystals and Liquid Crystals, 581(1): 45-51.

20. Zhang, J., Yu, C., Wang, L., Li, Y., Ren, Y. and Shum, K. (2014). Energy barrier at the N719-dye/CsSnI 3 interface for photogenerated holes in dye-sensitized solar cells. Scientific Reports, 4: 6954.

21. Lim, A., Manaf, N., Tennakoon, K., Chandrakanthi, R. L. N., Lim, L. B. L., Bandara, J. M. R. and Ekanayake, P. (2015). Higher performance of DSSC with dyes from Cladophora sp. as mixed co-sensitizer through synergistic effect. Journal of Biophysics: 1-8.

22. Galoppini, E. (2004). Linkers for anchoring sensitizers to semiconductor nanoparticles. Coordination Chemistry Reviews, 248(13-14): 1283-1297.

23. Kumara, N. T. R. N., Ekanayake, P., Lim, A., Iskandar, M. and Ming, L. C. (2013). Study of the enhancement of cell performance of dye sensitized solar cells sensitized with Nephelium lappaceum (F: Sapindaceae). Journal of Solar Energy Engineering, 135: 031014.

24. Leonat, L., Sbârcea, G. and Bran̂zoi, I. V. (2013). Cyclic voltammetry for energy levels estimation of organic materials. UPB Scientific Bulletin, Series B: Chemistry and Materials Science, 75: 111-118.

25. Kumara, N. T. R. N., Ekanayake, P., Lim, A., Liew, L. Y. C., Iskandar, M., Ming, L. C. and Senadeera, G. K. R. (2013). Layered co-sensitization for enhancement of conversion efficiency of natural dye sensitized solar cells. Journal of Alloys and Compounds, 581: 186-191. 
Nur Ezyanie et al: CO-SENSITIZATION OF NATURAL SENSITIZERS EXTRACTED FROM RENGAS (Gluta spp.) AND MENGKULANG (Heritiera elata) WOOD WITH RUTHENIUM DYE (N719) TO ENHANCE THE PERFORMANCE OF DYE-SENSITIZED SOLAR CELLS

26. Ooyama, Y. and Harima, Y. (2012). Photophysical and electrochemical properties, and molecular structures of organic dyes for dye-sensitized solar cells. ChemPhysChem, 13(18): 4032-4080. 